\title{
Фрагментация международного права
}

\author{
Колодкин Р.A.*
}

Boпрос о т.н. фрагментации международного права стал в конце прошлого века примечательной чертой дискуссии среди специалистов по международному праву. Ему посвящены научные работы, им занимается Комиссия международного права ООН (далее - КМП), его обсуждают государства в Шестом комитете Генеральной Ассамблеи $\mathrm{OOH}^{1}$.

- Колодкин Роман Анатольевич - член Комиссии международного права ОOH.

Автор благодарит С.С. Саренкову, которая была его ассистентом на 59-й сессии Комиссии международного права, за помощь в подготовке данной статьи.

${ }^{\prime}$ См., например: Brownlie I. Problems conceming the unity of intemational law. In: Le droit a l'heure de sa codification. Etudes en l'honneur de Roberto Ago, vol. I (Universita di Genova, Instituto di Diritto Internazionale e della Navigazione della Facolta di Guirisprudenza, Giuffre Milano, ed.1987). P. 153-162; Wellens K.C. Diversity in secondary rules and the unity of international law: some reflections on current trends. In: 25, Netherlands Yearbook of International Law (1994). P. 3-57; Sur S. The State between Fragmentation and Globalization. In: 3, European Journal of International Law (1997). P. 42I-434; Treves T. Recent trends in the settlement of international disputes. In: Cursos Euromediterraneos Bancaja de Derecho Internacional, vol. I, 1997. P. 395-436; Chamey J.I. International Law and Multiple International Tribunals, Recueil des Cours, Academie de Droit International, 271 (1998). P. 101-382; Symposium on "Proliferation of International Tribunals: Piecing Together the Puzzle", New York Journal of Intemational Law and Politics, vol. 31, № .4 (1999). P. 679-970; Dupuy P-M. Multiplication des jurisdictions internationals et dangers de fragmentation de l'ordre juridique international. In: CEBDI, vol. III, 1999. P. 265-281; Casanovas O. Unity and Diversity in Public International Law, Martinus Nijhoff Publ., The Hague/New York/London, 2001; ASIL, Proceedings of the $96^{\text {th }}$ Annual Meeting, March 13-16, 2002. P. 368-380; for more bibliography see: Koskenniemi M. \& Leino P. Fragmentation of International Law? Postmodem Anxieties, 15(3) Leiden Journal of Inemational Law (2002). P. 553-579; Brown C. Review Essay "The Proliferation of International Courts and Tribunals: Finding Your Way through the Maze", Melbourne Joumal of International Law, vol. 3, 2002. P. 453-475. See also speeches by G. Guillaume, President of the International Court of Justice, to the General Assembly of the United Nations of 26 Oct. 2000 and of 30 Oct. 2001 and to the Sixth Committee of the General Assembly of 27 Oct. 2000 and of 31 Oct. 2001, www.icj-cij.org/icjwww/ipresscom/SPEECHES/ iSpeechPresident_Guillaume. Краткое изложение дискуссии в Шестом комитете Генеральной Ассамблеи ООН см. в: United Nations Doc. A/CN.4/513, 15 Feb. 2001, paras. 379-380; UN Doc. A/CN.4/529, 14 Jan. 2003, paras. 215-229; UN Doc. A/CN.4/537, 21 Jan. 2004, paras. 218-231. Безусловный интерес представляют итоги работы по данной теме 56-й сессии КМП. (См. Report of the International Law Commission on the work of its fifty-sixth session (3 May - 4 June and 5 July - 6 August 2004). General Assembly, Official Records, Fifty-ninth session, Supplement № 10 (A/59/10). 
Фрагментация ${ }^{2}$, т.е. распад, разделение или разрушение целого на отрывочные, не полные, не связанные между собой части, применительно к системе международного права (если, конечно, исходить из того, что она существует) - явление, думается, негативное. Тем не менее в Шестом Комитете Генеральной Ассамблеи ООН представители некоторьх государств отмечали, что КМП должна уделить внимание не только негативным, но и позитивным аспектам фрагментации ${ }^{3}$. Об этом же говорилось в Исследовательской группе, созданной КМП для рассмотрения темы фрагментации. Исследовательская группа пришла к выводу о том, что «название темы «Риски, проистекающие из фрагментации международного права» (которую начала рассматривать КМП. - Р.К.) не вполне адекватно, поскольку явления, обозначаемые термином «фрапментация», представлены в слишком негативном свете». Было решено изменить название темы на менее алармистское: «Фрагментация международного права: трудности, обусловленные диверсификацией и расширением сферы охвата международного права» ${ }^{4}$.

Что имеют в виду, когда говорят о фрагментации международного права? Фрагментацию или, по крайней мере, ее угрозу видят в пролиферации международно-правовых норм и институтов, в «автономности» или «самодостаточности» некоторых международно-правовых режимов, в распространении международного права на те сферы отношений, которые раньше не считались подходящими для международно-правового регулирования. Указывают на регионализацию и специализацию международного права, в частности, в таких областях, как права человека и международная торговля, на создание международных судов и других органов, применяющих и толкующих международное право и обладаюших компетенцией по одним и тем же или частично совпадающим вопросам. Отмечается, что все это приводит к конфликтам между нормами и режимами, толкованием и применением одних и тех же норм в различных ситуациях, распаду целостной и гомогенной международно-правовой системы ${ }^{5}$. Или что «сис-

2 «Фрагмент» - это отрывок текста, музыкального произведения, обломок, остаток древнего произведения. «Фрагментарный»-являющийся фрагментом, сохранившийся лишь в обломках, остатках; отрывочный, неполный. См., например: Ожегов С.И. Словарь русского языка. М., «Русский язык», 1990. С. 855.

${ }^{3}$ UN Doc. A/CN.4/529, 14 Jan. 2003, paras. 218-220; UN Doc. A/CN.4/537, 21 Jan. 2004, paras. 220.

4 Организация Объединенных Наций. Генеральная Ассамблея. Официальные отчеты. Пятьдесят седьмая сессия. Дополнение № 10 (А/57/10), п.п. 494, 498, 500. 
тема международного права состоит из беспорядочных частей и элементов, имеющих различную структуру, и поэтому вряд ли можно говорить об однородном характере международного права» ${ }^{6}$.

Говорится об опасности институциональной фрагментации, выражающейся в неоднообразной, негомогенной деятельности возрастающего числа международных судебных и арбитражных органов, и об угрозе материальной фрагментации, связанной с конфликтами между нормами международного права. Чаще всего приводят следующие примеры ситуаций, свидетельствующих о фрагментации международного права.

В контексте пролиферации международных судов указывают на противоречия между мнением, высказанным Международным Судом в деле о военных и полувоенных действиях в и против Никарагуа 1986 года, и мнением Международного трибунала по бывшей Югославии (МТБЮ) по делу Тадича 1996 года. Международный Суд отметил, что государство несет ответственность за операции полувоенных формирований на территории другого государства в том случае, если оно осуществляет «эффективный контроль» над этими операциями. При этом Суд подчеркнул важность степени контроля? . МТБЮ решил, что для присвоения государству ответственности за такие действия достаточно, чтобы оно осуществляло «общий контроль» ${ }^{8}$. Делается вывод о том, что, таким образом, два суда по-разному истолковали и применили одну и ту же норму международного права.

В контексте диверсификации международного права, стремительного развития его правочеловеческой отрасли указывают на проблему оговорок к международным договорам в области прав человека. Речь, в частности, идет о том, что режим оговорок и возражений на них,

s UN Doc. A/CN.4/529, 14 Jan. 2003, paras. 216-217. М. Коскенниеми так описывает фрагментацию: «...возникновение и консолидация специальных режимов и технических поддисциплин: права человека, право окружающей среды, торговое право, применение силы и т.д. В каждой из этих областей партикулярные интересы проецируются как универсальные, что приводит к нормативным и юрисдикционным конфликтам». Koskenniemi M. What Is International Law For? In: International Law. Ed. by M. D. Evans, Oxford Univ. Press, 2003. P. 109.

' Хафнер Г. «Риск фрагментации международного права». Организация Объединенных Наций. Генеральная Ассамблея. Офишиальные отчеты. Пятьдесят пятая сессия. Дополнение № 10 (A/55/10). С. 369.

${ }^{7}$ Military and Paramilitary Activities in and against Nicaragua (Nicaragua v. United States of America), Merits, Judgment, I.C.J. Reports, 1986. P. 14, at P. 52, 54-55, paras. 109, 115. ${ }^{8}$ ICTY: Prosecutor v. Tadic, 38 I.L.M. 1518 (1999). P. 154-159, paras. 117-162. 
зафиксированный в Венской конвенции о праве договоров 1969 года (далее - ВКПД), не применяется, когда речь идет о международных договорах в области прав человека. При этом указывают на позицию, занятую в отношении оговорок органами, созданными на основе этих договоров. Так, из Общего комментария № 24 Комитета по правам человека следует, что этот орган считает себя вправе признавать недействительной оговорку, сделанную государством при принятии обязательств по Международному пакту о гражданских и политических правах 1966 года. Соответственно в таком случае данное государство будет связано положениями этого договора в полном объеме 9

Другой пример - деятельность Европейского суда по правам человека. В деле Белилос против Швейцарии 1988 года Суд, решив, что обладает юрисдикцией по вопросу о действительности оговорки или толковательного заявления к Европейской Конвенции по правам человека, признал, что толковательное заявление (вопрос о действительности которого Суд на самом деле рассматривал так, как если бы речь шла об оговорке), которое сделала Швейцария, было недействительным и что Швейцария была связана Конвенцией в полном объеме ${ }^{10}$.

Как на свидетельство об утрате международным правом единства указывают на появление т.н. «автономных» (autonomous) или «самодостаточных» (self-contained) режимов. В качестве примера такого режима называют режим оговорок к договорам о правах человека или правовую систему ВТО. Отмечают, в частности, что в документах этой организации и решениях ее Органа по разрешению споров не получают достаточного отражения нормы общего международного права.

Упоминается и о т.н. параллельном регулировании одних и тех же вопросов на универсальном и региональном уровнях. Например, говорят о сосушествовании двух конвенций о несудоходных видах использования международных водотоков: универсальной Конвенции о праве несудоходных видов использования международных водотоков, принятой ООН в 1997 году,

и региональной Европейской конвенции о международных водотоках 1992 года" ${ }^{11}$.

${ }_{9}$ UN Doc. CCPR/C/21/Rev. 1/Add. 6, 11 November 1994.

${ }^{10}$ ECHR, Belilos judgment of 29 April 1988, Series A № 132. P. 24-28, paras. 50-60.

" Об этих и других примерах фрагментации см., в частности: Хафнер Г. Указ. соч.; Доклад Исследовательской группы КМП по теме фрагментации в: Организация Объединенных Наций. Генеральная Ассамблея. Официальные отчеты. Пятьдесят восьмая сессия. Дополнение № 10 (А/58/10), п. 419. 
Действительно ли это свидетельства неизбежной фрагментации международного права? Можно ли вообще говорить о международном праве как о целостной системе? Если международное право - это система, то является ли она полной, всеобъемлющей? Или же мы имеем дело с фрагментарным явлением, и международное право бессистемно регулирует одни аспекты отношений и оставляет неурегулированными другие, а его нормы при этом еще и зачастую конфликтуют между собой и конфликты эти неразрешимы?

Примерно с середины 60-х годов прошлого столетия в советской, а затем российской международно-правовой доктрине начало формироваться и потом закрепилось в качестве главенствующего мнение о том, что международное право - это прежде всего система норм ${ }^{12}$. С теми или иными различиями на это указывают практически все современные определения международного права в российской доктрине ${ }^{13}$.

Российская доктрина исходит из структурированного, иерархического характера системы международного права, в которой главенствующая роль принадлежит его основным принципам, составляюшим идейную и нормативно-правовую основу системы ${ }^{14}$. Считается, что

${ }^{2}$ См.: Фельдман Д.И. Система международного права. Изд-во Казанского ун-та, 1983. Историю формирования системного подхода в советской международно-правовой науке см. в: Курс международного права. В 7 томах. Том 1. Понятие, предмет и система международного права / Под ред. Ю. Баскина, Н. Крылова, Д. Левина и др. М.: Наука, 1989. C. 253-256.

Как отмечает С. Черниченко, слова «прежде всего» целесообразно употребить в этом контексте потому, что понятие международного права не сводится только к системе норм. См.: Черниченко С. Теория международного права. В 2 томах. Том 1. Современные теоретические проблемы. М.: «НИМП», 1999. С. 15.

В качестве примера нетрадиционного (или не вполне традиционного) для отечественной доктрины взгляда на международное право отметим статью С.Л. Рогожина, в которой автор по сути соглашается с упомянутой выше концепцией Г. Хафнера. Рогожин С.Л. Мифы права. Опыт парадоксального анализа международного публичного права // МЖМП. 2003. № 3. С. 16-33.

${ }^{13}$ См., например: Международное право / Под ред. В.И. Кузнецова. М.: Юрист, 2001. С. 27; Международное право / Под ред. Г.В. Игнатенко и О.И. Тиунова. 3-е изд. М.: Норма, 2003. С. 6; Международное право / Под ред. Е.И. Усенко и Г. Шинкарецкой. М.: Юрист, 2003. С. 17; Международное право / Под ред. Ю.М. Колосова и Э.С. Крнвчиковой. М.: Международные отношения. 2001. С. 15; Международное публичное право / Под ред. К.А. Бекяшева. 3-е изд. М.: Проспект, 2004. С. 16; Международное право / Под ред. Г.И. Тункина. М.: Юридическая литература, 1994. С. 10; Лукашук И.И. Международное право. Общая часть. М.: БЕК, 1996. С. 1, 98-101.

${ }^{14}$ Курс международного права, т. 1, С. 261. И.И. Лукашук к основным юридическим и морально-политическим системообразущим факторам относит не только принципы, но и цели международного права. См.: Лукашук И.И. Указ. соч. С. 98-101, 116-120. 
основные принципы - это наиболее важные, коренные общепризнанные нормы международного права, обладающие высшим юридическим авторитетом ${ }^{15}$.

По преобладающему среди российских ученых мнению, основные принципы международного права являются нормами jus cogens, и все другие нормы международного права должны им соответствовать ${ }^{16}$. Вместе с тем, как писал Г.И. Тункин, «не было проведено достаточных исследований, чтобы доказать, все ли основополагающие принципы являются императивными или, как можно предположить, некоторые из них лишь частично императивны» ${ }^{17}$. (О частичной императивности основных принципов или, по крайней мере, некоторых из них, пишет, например, Р.А. Мюллерсон. Однако при этом он отмечает, что, как бы ни обстояло дело с природой jus cogens основополагающих принципов, без них само существование международного права как когерентной системы действительно было бы под вопросом ${ }^{18}$.)

В качестве основных принципов международного права в нашей доктрине рассматриваются обычно принципы Устава ООН, содержание которых раскрыто в Декларации о принципах международного права, касающихся дружественных отношений и сотрудничества между государствами в соответствии с Уставом ООН, принятой Генеральной Ассамблеей ООН в 1970 году, и в Декларации принципов Заключительного акта Совещания по безопасности и сотрудничеству СБСЕ 1975 года.

Вряд ли можно говорить о существовании в международном праве некоего исчерпывающего перечня его основных принципов. Напри-

15 См., например: Международное право // Под ред. Е.И. Усенко и Г.Г Шинкарецкой. С. 41 .

${ }^{16}$ Курс международного права, Т. 1, С. 261. См. также: Международное право // Под ред. Г.И. Игнатенко и О.И. Тиунова. С. 99; Международное право // Под ред. В.И. Кузнецова. С. 124; Международное право // Под ред. Ю.М. Колосова и Э.С. Кривчиковой. С. $41-42,47-48$.

${ }^{17}$ Tunkin G. International Law in the Intemational System, Receuil des Cours, Academie de Droit International,

IV, 147 (1975). Р. 98. К выводу о «неполной» когентности некоторых основных прннципов международного права пришел в свое время и Л.Н. Шестаков. См.: Шестаков Л.Н. Императивные нормы в системе современного международного права. Изд-во Московского университета, 1981. С. 93-119.

${ }^{18}$ Mullerson R. Ordering anarchy. International law in international society. Martinus Nijhoff Publ. The Hague/Boston/London, 2000. P. 156-159. Здесь же см. анализ западной доктрины об основных принципах международного права. 
мер, наряду с упомянутыми, к числу основных принципов следовало бы отнести принцип ответственности государства за международнопротивоправное деяние ${ }^{19}$ или связанный с принципом суверенитета принцип, согласно которому ограничения суверенитета в международном праве не могут презюмироваться и поэтому поведение государства, не запрещенное международным правом, правомерно.

Помимо основных принципов, российские авторы выделяют т.н. отраслевые принципы международного права, т.е. нормы, являющиеся наиболее общими и важными для его отраслей ${ }^{20}$. Важно, что отраслевые принципы зачастую являются пронзводными от основных принципов и в любом случае не могут им противоречить.

Этот системный взгляд на международное право, разделяемый автором настоящей статьи, отнюдь не предполагает, что международное право является статичным, гомогенным явлением. Оно развивается вместе с теми общественными отношениями, которые оно регулирует, и отражает все многообразие этих отношений. Наряду с немногочисленными нормами основополагающего характера, защищающими базисные ценности человечества и имеющими императивный характер, существуют многочисленные диспозитивные нормы. От этих норм, в отличие от норм императивных, государства могут отходить в заключаемых между собой соглашениях. Именно таким образом наряду

19 Как отмечает И.И. Лукашук, ответственность - «прежде всего, это принцип международного права, в соответствии с которым всякое противоправное деяние влечет за собой ответственность виновного субъекта по международному праву». Лукашук И.И. Указ. соч. С. 179.

20 Например, применительно к международному воздушному праву говорят о принципе суверенитета государства над его воздушным пространством, принципе разрешительного порядка международных полетов и перевозок в суверенном воздушном пространстве и принципе свободы полетов за пределами государственной территории. Для международного экономического права считают отраслевыми принципы экономического сотрудничества, суверенитета государств над природными ресурсами, взаимной выгоды, экономической недискриминации, а также принципы нанболее благоприятствуемой нации и предоставления национального режима. В качестве отраслевых принципов международного права окружающей среды указывают принцип, согласно которому государства не должны в результате деятельности в рамках их юрисдикции или контроля причинять ущерб окружающей среде других государств или районов за пределами действия национальной юрисдикции. Как и в международном экономическом праве, в праве окружающей среды выделяют принцип суверенитета государства над своими национальными природными ресурсами; как о формирующемся (а некоторые авторы - как об уже сформировавшемся) говорят об отраслевом принципе предусмотрительного подхода, или принципе предосторожности, и некоторых других принципах. 
с нормами общими зачастую возникают и существуют нормы специальные, наряду с универсальными - партикулярные, локальные. Сегодня новые универсальные и партикулярные, общие и специальные нормы встраиваются в существующую международно-правовую систему, развивая и дополняя ее.

Общепризнанно, что сфера регулирования международного права все время расширяется. Оно распространяется на те области, в которых международное сотрудничество раньше не осуществлялось (например, охрана окружающей среды). Оно регулирует те отношения, которые раньше относились к сфере исключительно внутренних дел государства и регулировались только национальным правом (например, права человека). Оно имеет дело с субъектами, деятельность которых напрямую им прежде не затрагивалась (индивиды, юридические лица, международные неправительственные организации). Новые международно-правовые нормы возникают все время. Это, однако, не означает, что существующее международное право фрагментарно и, соответственно, изобилует пробелами.

Конечно, не все конкретные отношения между государствами уреғулированы конкретными международно-правовыми нормами. В этом смысле можно говорить о существовании в системе международного права определенных пробелов. Однако вряд ли можно согласиться с присущим специалистам, отрицающим системный, всеобъемлющий характер международного права мнением, согласно которому международному порядку присущи многочисленные «лакуны» ${ }^{21}$. По существу любое поведение государства можно оценить с точки зрения принципов международного права, характеризуя это поведение в каждом случае как правомерное или неправомерное. Это возможно, поскольку, как отмечал Г.И. Тункин, основные принципы международного права покрывают все сферы отношений между государствами ${ }^{22}$.

Оценить правомерность поведения государства в любом случае можно и с точки зрения принципа, в соответствии с которым поведение, не запрещенное международным правом, правомерно. При рассмотрении вопроса о правомерности применения ядерного оружия в Международном Суде ряд стран, включая Россию, отмечал, что «государства свободны в том, что касается утрозы использования или использова-

${ }^{21}$ См., например: Carreau D. Droit international public., 7-th edition, Paris, ed. A.Pedone, 2001. Р. 35-36.

${ }^{2}$ Международное право / Под ред. Г.И. Тунсина М.: Юридическая литерегура, 1994. С. 51. 
ния ядерного оружия, до тех пор, пока не будет показано, что они обязаны не делать этого со ссылкой на запрет в договорном или обычном международном праве» ${ }^{23}$. Еще в 1927 году в решении по делу Лотус Постоянная Палата Международного Правосудия указала, что «ограничения независимости государств не могут... презюмироваться» и что международное право оставляет государствам широкий простор для действий по своему усмотрению, «который ограничен лишь... запретительными нормами» ${ }^{24}$. В этом же ключе Международный Суд в деле о военных и полувоенных действиях в и против Никарагуа отметил: «...в международном праве нет норм иных, чем те, которые могут приниматься заинтересованными государствами договорным или другим путем, которыми уровень вооружений суверенного государства может быть ограничен, и этот принцип действителен для всех государств, без исключения $)^{25}$.

${ }^{23}$ Legality of the Threat or Use of Nuclear Weapons, I.C.J. Rep., 1996.P. 226, at P. 238, para. 21.

2f P.C.I.J., Series A, № 10, Sept. $7^{\text {th }}$, 1927, Collection of judgments, The case of the S.S." Lotus", P. 18 and 19.

${ }^{25}$ Military and Paramilitary Activities in and against Nicaragua (Nicaragua v. United States of America), Merits, Judgment, I.C.J. Reports, 1986. P. 14, para. 269. Интересно мнение О. Казановаса: «Говорят, что пробел существует, когда считается, что правовая система не содержит нормы, которую стонло бы иметь. В таком случае пробел - это не столько пробел, сколько критика сушествующего права и предложение относительно новой нормы de lege ferenda; можно назвать такие пробелы пробелами de lege ferenda. Термин «пробел» употребляется и в другом смысле - для обозначения ситуации отсутствия определенных норм по соответствуюшим вопросам. Это т.н. технический пробел. Отсутствие на определенном этапе норм, регулирующих деятельность в космосе, было пробелом нормы, но не права, т.к. есть возможность применения других, более общих правовых предписаний, которые могут адекватно решить проблему, не урегулированную специальной нормой. Кроме того, говорят, что пробел существует, когда, несмотря на наличие норм, относяшихся к вопросу, рассматриваемому судом, эти нормы не учитывают ни исключительный характер соответствуюшего случая, ни ограничения, которые могут считаться необходимыми. Это «неуместные пробелы» или «скрытые пробелы». По мнению О. Казановаса, «все правовые системы стремятся избегать пробелов или ограничивать их. ...Применительно к проблеме полноты права этот принцип (ограничения независимости государств не могут презюмироваться. - Р.К.) означал бы в международном праве, что все, что явно выраженно не запрещено, разрешено». Однако, добавляет он, «возможно, нельзя утверждать, что этот принцип применяется во всех случаях, относящихся к международной правовой системе». Автор продолжает: «Консультативное заключение Международного Суда в деле о правомерности применения или угрозы применения ядерного оружия показывает трудности, которые могут возникать из-за отсутствия применимых норм. ...Отсутствие специфических норм, касаюшихся угрозы или использования ядерного оружия, 
В то же время очевидно, что для эффективного международно-правового регулирования одних основных или отраслевых принципов недостаточно. Для этого необходимы конкретные нормы ${ }^{26}$.

Международное право по определению многообразно или разнообразно. Его нормы являются продуктом взаимодействия государств с различными уровнями экономического и политического развития, интересами, идеологиями, традициями, культурами, правовыми школами т.д. Это усугубляется в основном горизонтальным характером международной системы, наличием в ней различных региональных, специализированных отраслей или подсистем. В то же время нельзя не признать, что даже в период наиболее явно проявлявшегося идеологического, политического, ценностного и экономического разобщения современного мира - в эпоху холодной войны и глобального противоборства двух систем - капиталистической и социалистической общее, универсальное международное право переживало период бурного развития.

В тот период были также распространены пессимистические взгляды на возможность существования общего международного права в условиях конфликта двух систем и появления новых независимых государств в результате деколонизации, много говорилось о перспективах распада существуюшей универсальности международного права $^{27}$. Казалось бы, для таких взглядов были достаточные основания. Группы государств, объединенные географическим положением, экономикой, разделяемой ими идеологией, ценностями, политическими устремлениями и т.п., не просто, как прежде, создавали и развивали свои региональные правовые подсистемы. Социалистические страны настаивали на существовании параллельно с общим международным правом своего, особого содержательно, идеологически и политически, «социалистического международного права». Нормы «социалистического международного права», основанного на принципах «социалистического интернационализма», с точки зрения социалистических

не приводит к образованию такого правового вакуума, который не мог бы быть заполнен нормами и принципами общего характера, такими как положения Устава ОOH, касающиеся законной самообороны, и принципами международного гуманитарного права». О. Casanovas. Op. cit. P. 92-96.

${ }^{26}$ См. также: Международное право / Под. ред. Г.И. Тункина. М.: Юридическая литература, 1994 C. 51.

${ }^{27}$ Подробное описание этих взглядов см. в: Тункин Г.И. Теория международного права. М.: Международные отношения, 1970. С. 24-40. 
государств, регулировали отношения между ними, заменяя в этих отношениях принципы общего международного права. Эти принципы социалистической законности в отношениях между социалистическими государствами были "lex specialis" по отношению к нормам общего международного права» ${ }^{28}$.

Однако именно в это время общее международное право начало стремительно развиваться. Принципы неприменения силы и угрозы силой, мирного разрешения споров, уважения прав человека, самоопределения, территориальной целостности, т.е. те основополагающие нормы, которые определяют лицо и систему современного международного права, стали общепризнанными. Именно этот период стал «золотым веком» кодификации и прогрессивного развития международного права: морского права, права договоров, дипломатического и консульского права, международного права в области прав человека, гуманитарного права, права международной безопасности, космического права и т.д. Это стало возможным главным образом вследствие того, что, несмотря на все различия, государства объективно оставались связанными некоторыми общими высшими ценностями, прежде всего такими, как мир и безопасность. Важно, что государства осознавали необходимость закрепления этих ценностей в общеобязательных юридических правилах.

Распад «социалистического лагеря», прекращение мирового противоборства двух идеологий и, соответственно, холодной войны в сочетании с возникновением феномена глобализации создали объективные условия для дальнейшей универсализации международного права, развития его системы, углубления транснационального характера его воздействия. Появление глобальных вызовов, которые иногда называют среди факторов, ведущих к фрагментации международного права, на самом деле также объективно диктует необходимость поиска прежде всего глобальных международно-правовых ответов. Другое дело - удастся ли международному сообществу их выработать.

${ }^{28}$ I. Scobbie, Some common heresies about international law. In: International law. Ed.by M.D.Evans. P. 75. Однако Г.И. Тункин писал, что поскольку основные принципы общего международного права имеют характер јus cogens, принципы соииалистического интернационализма не могут им противоречить. Соответственно они не превалируют над принципами общего международного права, а лишь развивают, дополняют и, поэтому будучи специальными нормами, заменяют общие нормы международного права в отношениях между социалистическими государствами. См.: Тункин Г.И. Теория международного права, С. 503-506. 
В отсутствие глобальных международно-правовых решений начинается их поиск на других уровнях. Характерный пример - разработка антитеррористических договоров на региональном уровне в ситуации, когда переговоры по т.н. всеобъемлющей конвенции по терроризму в $\mathrm{OOH}$ не продвигаются уже в течение нескольких лет.

Очевидно, что сохранились многие различия между государствами, в силу которьх будут продолжать существовать и возникать новые региональные, двусторонние и другие не универсальные правовые нормы. Однако если уж все связанные с противоборством двух систем проблемы не помешали становлению системы международного права, не разрушили ее целостность, то тем более вряд ли можно рассматривать фрагментацию как реальную угрозу системе международного права в эпоху глобализации. Во всяком случае объективных предпосылок для фрагментации системы международного права сейчас, как представляется, нет. Следует также иметь в виду, что основными создателями и хранителями международного права являются государства. Они же, судя по дискуссии в Шестом комитете Генеральной Ассамблеи ООН, по их реакции на деятельность различных международньг судебньх органов, ВТО и других международных органов, по крайней мере пока, не воспринимают эту деятельность как несушую угрозу целостности международно-правовой системы. Закономерна в этой связи и упомянутая выше эволюция, которую претерпела тема фрагментации в КМП.

Методологически КМП правильно решила рассматривать то, что называют фрагментацией, с точки зрения уже сложившихся в международном праве подходов к ситуациям конфликтов между различными нормами ${ }^{29}$. Вместе с тем за рамками Комиссии такой «статический» подход, когда анализируются конфликты между уже существуюцими нормами, стоило бы расширить.

${ }^{29}$ Следующие темы были включены в 2002 году в программу работы Исследовательской группы КМП: (а) Функция и сфера применения нормы lex specialis и вопрос об «автономных режимах»; (b) толкование договоров в свете «любых соответствующих норм международного права, применяемых в отношениях между участниками» (п. 3 c) cr. 31 ВКПД) в контексте общей зволюции международного права и озабоченностей международного сообщества; (c) применение последовательно заключенных договоров, относящихся к одному и тому же вопросу (ст. 30 ВКПД); (d) изменение международных договоров только во взаимоотношениях между определенными участниками (ст. 41 ВКПД); (е) иерархия в международном праве: jus cogens, обязательства erga omnes, статья 103 Устава ООН как коллизионные нормы. Организация Объединенных Наций. Генеральная Ассамблея. Официальные отчеты. Пятьдесят восьмая сессия. Дополнение № 10 (A/58/10), п. 413. 
Деятельность различных международных органов, осуществляющих применение и толкование международного права, создание региональных и иных партикулярных международно-правовых норм надо рассматривать в контексте существующей международно-правовой системы, ее основополагаюших принципов. При этом важно принимать во внимание, что эта система постоянно развивается, следуя за изменениями, происходящими в мире, а также то, что создателями международно-правовых норм являются в конечном итоге именно государства. Сами по себе международные органы по рассмотрению споров не создают нормы международного права (если, конечно, их не наделяют этим правом государства). Поэтому деятельность международных органов, применяющих и толкующих международное право, (прежде всего речь идет об органах, в которых представлены не государства, а судьи или эксперты в личном качестве) необходимо рассматривать и оценивать с учетом реакции на нее государств, их практики и оріnio juris, следующими за решениями этих органов.

Наряду с этим следует иметь в виду, что создание международноправовых норм, приход новых норм на смену старым - это процесс, который может быть противоречивым. Зачастую поведение государств первоначально может выглядеть как нарушение сушествующей нормы права, и лишь впоследствии выясняется, что на самом деле это было начало формирования новой нормы. Кроме того, в отсутствие конкретной международно-правовой нормы, или когда ее содержание еще не до конца ясно, решения международных органов в примерно аналогичных ситуациях могут различаться. Необходимо время и прояснение позиций не только и не столько международных органов, сколько, в первую очередь, государств на сей счет, чтобы стало ясно, каково содержание соответствующей международно-правовой нормы, находящейся в процессе становления. В этой связи вопрос фрагментации должен рассматриваться также с точки зрения формирования обычных норм международного права и их взаимоотношения с договорными нормами ${ }^{30}$.

Проанализируем упомянутые примеры фрагментации как с. точки зрения известных принципов разрешения конфликтов между между-

${ }^{30}$ В этом контексте см. анализ процесса изменения существующих норм международного права в ходе возникновения новых обычных норм, предлагаемый Р. Хиггинс. (Higgins R. Problems \& Progress. International law and how we use it. Oxford Univ. Press, 1995. P. 18-22, 28-32.) 
народно-правовыми нормами (общие - специальные; последующие предыдущие; императивные - диспозитивные), так и в контексте системы международного права. При этом следует принять во внимание, что создание нормы - это процесс, в котором решающая роль принадлежит государствам.

В решениях Международного Суда в деле о военной и полувоенной деятельности в и против Никарагуа ${ }^{31}$ и МТБЮ в деле Тадича ${ }^{32}$, в той их части, которая касается вопроса о контроле со стороны государства за действиями лица или группы лиц для целей присвоения этому государству их поведения, речь не идет о конфликте различных норм. Эти решения могут рассматриваться как свидетельства существования или становления международно-правовой нормы, согласно которой действия лица, группы лиц или негосударственных образований присваиваются государству, если оно осуществляет контроль над этими лицами или образованиями при осушествлении этих действий.

Этот вывод подкрепляется положениями статьи 8 проекта статей об ответственности государств за международно-противоправные деяния, подготовленных КМП, и комментарием Комиссии к этой статье, который опирается на эти решения ${ }^{33}$. В то же время вывод Международного Суда о том, что для возникновения юридической ответственности государства необходимо, чтобы такой контроль был эффективным, не был поддержан не только МТБЮ, но и КМП. Комиссия не включила критерий уровня контроля в упомянутую статью 8. Отметив, что и с юридической, и с фактической стороны данные дела различаются, КМП указала: «В любом случае вопрос о том, была ли степень контроля государства за тем или иным поведением достаточной для того, чтобы присвоить ему это поведение, должен решаться с учетом обстоятельств каждого конкретного дела» ${ }^{34}$. Различия в позициях Международного Суда и МТБЮ - это не пример фрагментации международного права,

${ }^{31}$ Military and Paramilitary Activities in and against Nicaragua (Nicaragua v. United States of America), Merits, P. 62, 64-65, paras. 109,115.

${ }^{32}$ ICTY: Prosecutor v. Tadic, 38 I.L.M.1518 (1999). P. 1541-1549, paras. 117-162.

${ }^{33}$ Организация Объединенных Наций. Генеральная Ассамблея ООН. Официальные отчеты. Пятьдесят шестая сессия. Дополнение № 10 (A/56/10). С. 96-101. Статья 8 гласит: «Поведение лица или группы лиц рассматривается как деяние государства по международному праву, если это лицо или группа лиц фактически действует по указаниям либо под руководством или контролем этого государства при осушествлении такого поведения».

${ }^{34}$ Там же, С. 99. 
а элементы процесса формирования обычной нормы международного права, сформулированной также позднее КМП в статьях об ответственности государств. При этом текст упомянутой статьи 8 свидетельствует в пользу того, что уровень контроля не является элементом этой нормы. Однако de lege lata об этом можно будет определенно говорить только по мере выяснения отношения к нему государств.

Упомянутое выше толкование Европейским Судом по правам человека режима оговорок применительно к Европейской конвенции о правах человека и основных свободах в деле Белилос было подтверждено затем в деле Лоизиду ${ }^{35}$. При рассмотрении этих дел Европейский Суд, во-первых, утвердил свое право решать вопрос о действительности оговорок к Европейской конвенции о правах человека, тогда как по общей норме права международных договоров это прерогатива государств - участников соответствующего договора. Во-вторых, Суд в деле Лоизиду, так же как и в деле Белилос, решил вопрос о «территориальных ограничениях», содержащихся в заявлениях Турции по статьям 25 и 46 Конвенции, по существу: эти ограничения (ограничительные заявления) были признаны недействительными, а Турция - связанной соответствуюшими положениями Конвенции без предусмотренных ее заявлениями ограничений. При этом по сути, как и в деле Белилос, вопрос о действительности заявлений рассматривался Судом как вопрос о действительности оговорок ${ }^{36}$. Этот вывод явно отличается от режима оговорок, предусмотренного ВКПД ${ }^{37}$. Сам Суд в целом обосновал свои действия и выводы специальным характером режима, установленного Европейской Конвенцией, и, соответственно, отличиями своей практики как специализированного суда от практики Международного Суда, который является «свободным» международным трибуналом, не имеющим связей с устанавливающим стандарты договором, таким как Европейская Конвенция ${ }^{38}$. Исследовательская группа КМП в своем докладе, принятом к сведению Комиссией, по сути,

\footnotetext{
${ }^{35}$ ECHR, Loizidou v. Turkey, (Preliminary objections), judgement of 23 March 1995, Ser. A no 310 . P. 31 , para. 94 .

${ }^{36}$ Ibid., paras. $68 \mathrm{f}$.

${ }^{37}$ Пункт 3 статьи 21 ВКПД гласит: «Если государство, возражающее против оговорки, не возражало против вступления в силу договора между собой и сделавшим оговорку государством, то положения, к которым относится оговорка, не применяются между этими двумя государствами в пределах сферы действия такой оговорки».

${ }^{38}$ ECHR, Loizidou v Turkey, (Preliminary objections), judgement of 23 March 1995, Ser. A № 310. P. 26-27, paras. $68,70,71,84,85$.
} 
согласилась с мнением Суда. Она квалифицировала эту ситуацию как конфликт, возникший в силу того, что в данном случае применимо специальное право ${ }^{39}$.

Хотелось бы отметить в этой связи следующее. Во-первых, этот конфликт разрешается в пользу специального и более позднего, в данном случае - регионального обычно-правового режима оговорок. Во-вторых, этот режим сложился (или складывается) вследствие не только деятельности Европейского Суда по правам человека, но и реакции европейских государств на эту деятельность. Члены Совета Европы не возражают против такой позиции Суда, хотя, например, вопрос об оговорках является на протяжении уже ряда лет предметом постоянной дискуссии в Комитете советников по международному публичному праву Совета Европы (CAHDI). Более того, в конце 90-х годов Комитетом была создана специальная группа экспертов по оговоркам к международным договорам. Дискуссия в группе, а затем и в CAHDI подтвердила, что практика в рамках Совета Европы по вопросам оговорок обладает определенной спецификой ${ }^{40}$. В подготовленной этой группой, одобренной CAHDI и затем принятой Комитетом министров Совета Европы Рекомендации об ответах на недопустимые оговорки к международным договорам отмечается, в частности, что когда ВКПД принималась, не было представления о дальнейшем развитии, в частности, в том, что касается формулирования оговорок общего характера и возрастающей роли контрольных органов, действующих на основе соответствующих договоров ${ }^{41}$. Большинство норм общего международного права в области права договоров, сформулированных в ВКПД, носит диспозитивный характер. Они могут быть изменены по соглашению между некоторыми участниками Конвенции. В рамках Совета Европы произошло изменение договорного режима в области оговорок, сформулированного в ВКПД, в результате возникновения регионального обычного специального режима, действующего в отношениях между государствами - членами Совета.

${ }^{39}$ Генеральная Ассамблея ООН. Офицнальные отчеты. Пятьдесят восьмая сессия. Дополнение № 10 (A/58/10), п. 419.

${ }^{40} \mathrm{See}$ : Ad hoc Committee of LEGAL ADVISERS ON PUBLIC UNTERNATIONAL LAW (CAHDI), GROUP OF EXPERTS ON RESERVATIONS TO INTERNATIONAL TREATIES (DI-E-RIT), MEETING REPORT, DI-E-RIT (99) 6, Strasbourg, 16/08/99; AD HOC COMMITTEE OF LEGAL ADVISERS ON PUBLIC INTERNATIONAL LAW (CAHDI), MEETING REPORT, CAHDI (99) 15, Strasbourg, 04/05/99. P. 9-10.

4! Council of Europe Committee of Ministers, Recommendation № R (99) 13, adopted on 18 May 1999. 
Иная ситуация складывается в связи с деятельностью Комитета по правам человека, функционируюшего в рамках Международного пакта о гражданских и политических правах 1966 года. Упомянутый выше Общий комментарий № 24 вызвал возражения государств, в частности США, Великобритании и Франции ${ }^{42}$. Как отмечает Дж. А. Фровейн, это показывает, что на универсальном уровне по-прежнему существует «нежелание государств принимать линию, проводимую сейчас в системе Европейской конвенции о правах человека и основных свободах ${ }^{43}$. Э. Аост, проанализировав итоги дискуссии в 1997 году по докладу КМП в Шестом Комитете Генеральной Ассамблеи, приходит к выводу, что почти все из 47 выступивших представителей государств «подтвердили, что режим Конвенции (ВКПД. - Р.К.) применяется ко всем договорам, и не согласились в различной степени с тем, что органы, наблюдающие за соблюдением договоров, обладают компетенцией для вынесения решений о допустимости или действительности оговорок» ${ }^{44}$. Таким образом, о становлении в рамках Международного пакта о гражданских и политических правах универсальной обычной специальной нормы, аналогичной норме, сложившейся в Европе, и, соответственно, об отходе на универсальном уровне от режима, предусмотренного общим международным правом, по крайней мере пока, говорить рано ${ }^{45}$. Однако нельзя исключать, что мы являемся свидетелями постепенной кристаллизации такой нормы. Думается, все будет зависеть от дальнейшей реакции государств на

${ }^{42}$ Observations on General Comment 24, 16 Human Rights Law Journal (1995) at 422-426. Анализ реакции этих государств см. в: B. Simma. Reservations to Human Rights Treaties - Some Recent Developments. In: G. Hafner, G. Loibl, A. Rest, L. Sucharipa-Behrmann and K. Zemanek (eds.). Liber Amicorum Professor Seidl-Hohenveldem - in honor of his $80^{\text {th }}$ birthday, 1998, Kluwer Law Int. P. 674-675; Y. Tyagi. The conflict of law and policy on reservations to human rights treaties. In: 71 British Yearbook of International Law (2000). P. 245-246.

${ }^{43}$ Frowien J.A. Reservations and the International ordre public. In: Theory of International Law at the Threshold of the $21^{\text {st }}$ Century, Essays in honor of Krsysztof Skubiszewski. Ed. By J. Makarczyk, Kluwer law int.,1996. P. 408.

${ }^{4+}$ Aust A. Modern Treaty Law and Practice. Cambridge University Press, 2000. P. 124. ${ }^{45}$ Й. Тьяги, утверждающий, что в результате деятельности Комитета на основе Пакта в отношении оговорок происходит становление режима lex specialis, все же признает, что «комментарии Комитета не являются частью твердого права оговорок». (Y. Tyagi. Op. cit. Р. 246.) Б. Симма указывает, что de lege ferenda правочеловеческие договорные органы $\mathrm{OOH}$ нуждаются - и заслуживают этого - в наделении их компетенцией по принятию юридически обязательных решений относительно допустимости и отделимости оговорок к договорам о правах. (B. Simma. Op. cit. P. 680) 
деятельность договорных органов в этой области. Что касается Комитета по правам человека, то позицию, сформулированную в Общем комментарии № 24, он подтвердил при рассмотрении дела Кеннеди ${ }^{46}$.

О режиме оговорок к договорам (региональным и универсальным) по правам человека иногда говорят как об автономном или самодостаточном режиме ${ }^{47}$. Оставляя в стороне дискуссию о самом понятии «автономный» или «самодостаточный» режим и его праве на существование $^{48}$, отметим, что ни практика Европейского Суда по правам человека, ни практика органов, созданных на основе универсальных договоров в этой сфере, не свидетельствуют об их автономности, самодостаточности или отделении от общего международного права. Упомянутый Общий комментарий № 24 содержит неоднократные ссылки на ВКПД и на отраженное в ней общее международное право, оперирует его положениями и понятиями ${ }^{49}$. Так же опирается на универсальные международно-правовые нормы в упомянутых выше делах Белилос и Лоизиду Европейский Суд по правам человека ${ }^{50}$. Это справедливо и в отношении других случаев, приводимых в качестве примеров автономных или самодостаточных режимов, в частности ВТО.

. Дж. Джексон, анализируя практику органа по рассмотрению споров ВТО, отмечает: «...Апелляционный Орган сделал достаточно ясным, что общее международное право релевантно и применяется в случае ВТО и его договорных приложений, включая ГАТТ. В прошлом

${ }^{46}$ Сообщение № 845/1999, Кеннеди против Тринидад и Тобаго (решение принято 2 ноября 1999 года, шестьдесят седьмая сессия). Док. ООН А/55/40, т. II, Приложение XI, A, пп. 6.4-6.7.

${ }^{47}$ Wellens K.C. Op. cit. P. 27.

${ }^{48}$ See Ibid.; Simma B. Self-contained regimes, 16 NYIL (1985); L.A.N.M.Barnhoorn, Diplomatic Law and Unilateral Remedies, 25 Netherlands Yearbook of International Law (1994). Р. 30-81. П-М. Дюпюи, например, называет «доктрину самодостаточных режимов» «вводящей в заблуждение» (P-M. Dupuy. The danger of fragmentation or unification of the international legal system and the International Court of Justice, International Law and Politics, vol. 31:753, 1999. P. 797).

${ }^{49}$ UN Doc. HRI/GEN/1/Rev.4, 7 Feb. 2000. P. 118-124.

${ }^{50}$ For ex., ECHR, Belilos judgement, paras. 42, 46; ECHR, Loizidou vs. Turkey (Preliminary objections), paras. 67, 90. Ссылки на общее международное право часты в практике ECПЧ, см., например: McElhinney v. Ireland [GC], № 31253/96, para. 38,ECHR 2001XI; Al-Adsani vs. The United Kingdom [GC], № 35763/97, paras. 54-55, 60-66, ECHR 2001-XI; Fogarty vs. The United Kingdom [GC], № 37112/97, paras. 37-38, ECHR 2001XI; Streletz, Kessler and Krenz vs. Germany, nos. 34044/96, 35532/97 and 44801/98, paras. 90 f., ECHR 2001-II; Bankovic and others vs. Belgium and others, № 52207/99, paras. 55-59, 73. 
это было предметом... вопросов, некоторые стороны утверждали, что ВТО - это «отдельный режим», неким образом изолированный от общего международного права. Апелляционный Орган достаточно ясно показал, что это не так, ссылаясь на принципы общего международного права, в частности на те из них, которые отражены в Венской конвенции о праве международных договоров, и которые Апелляционный Орган использует для толкования договоров» ${ }^{51}$.

Весьма убедительным является анализ важной роли международного права, и в частности общего международного права, в ВТО, проведенный Дж. Поувелином ${ }^{52}$.

М. Коскенниеми и П. Лейно полагают, что может казаться, что полностью самодостаточные режимы являются меньшей опасностью, чем полуавтономные режимы, которые применяют концепции общего международного права, но делают это специальным образом. В этом, считают они, корень проблемы: «не столько в появлении новых подсистем, сколько в использовании общего права новыми органами, представляющими новые взгляды, которые не идентичны взглядам, представленным в старых органах $)^{53}$.

Думается, однако, что речь не идет ни об автономности, ни о полуавтономности режимов. На самом деле имеет место естественное для международно-правовой системы появление норм (режимов), специальных по отношению к тем ее нормам (режимам), которые являются диспозитивными. Речь может идти и о формировании норм (режимов), не являющихся специальными, поскольку в соответствующей области нет общих диспозитивных международно-правовых норм, по отношению к которым возникающие нормы были бы специальными. Но в этом случае новые нормы все равно возникают на базе принципов международного права, которым они не могут противоречить. Это важно, в частности, для формирования региональных норм международного права.

st Jackson J. The jurisprudence of GATT and the WTO, Cambridge Univ. Press, 2000. P. 181. Автор приходит даже к более обшему выводу. Международное экономическое право, пишет он, «не может быть отделено от общего международного права или выделено из него. Деятельность и судебные дела в области международного экономического права содержат много практики, касающейся общих принципов международного права, особенно относящихся к договорному праву и практике». Ibid. P. 11.

s2 Pauwelyn J. The Role of Public International Law in the WTO: How Far Can We Go? 95 A.J.I.L. 535, $200 \mathrm{I}$.

${ }^{53}$ Koskenniemi M. \& Leino P. Fragmentation of intemational law? Postmodern anxieties. P. 561. 
Приведенный выше пример параллельного сушествования универсальной (1997 г.) и региональной (1992 г.) Конвенций о несудоходных видах использования международных водотоков не является примером фрагментации международного права. Налицо вполне обычная ситуация сосуществования универсального диспозитивного режима и специального регионального режима, при том, что последний появился раньше первого. Вопрос о том, какая норма подлежит применению в отношениях между двумя государствами - участниками обоих этих договоров, в данном случае должен решаться прежде всего с учетом п. 1 ст. 3 Конвенции 1997 года. В нем указывается: «В отсутствие соглашения об ином ничто в настоящей Конвенции не затрагивает права и обязательства государства водотока, вытекающие из действующих соглашений, участниками которых оно является на дату присоединения к настоящей Конвенции». Таким образом, приоритет отдается специальным нормам, действующим для соответствующих государств на момент их присоединения к Конвенции 1997 года, несмотря на то, что она принята позже этих норм ${ }^{54}$.

В ситуациях, аналогичных приведенной, региональное соглашение является отправной точкой для формирования универсальных норм. И наоборот. Универсальные договоры, подобные Конвенции 1997 года, становятся базисными, рамочными для последующих региональных соглашений ${ }^{55}$.

Сложнее обстоит дело, когда попытки согласовать универсальные нормы по универсально важным вопросам не приносят успеха inter alia из-за различия в позициях государств различных регионов, и государства начинают заключать различающиеся между собой региональные соглашения в данной области. Такая ситуация складывается, например, в сфере борьбы с терроризмом.

Попытки выработать универсальное определение терроризма для целей т.н. Всеобъемлющей конвенции по борьбе с терроризмом, что

${ }^{54}$ Пункт 2 статьи 3 Конвенции приглашает государства согласовывать специальные соглашения с ее основными принципами: «Независкмо от положений пункта 1 участники соглашений, упомянутых в пункте 1, могут при необходимости рассматривать возможность согласования таких соглашений с основными принципами настоящей Конвенции».

s5 В пункте 3 статьи 3 Конвенции указывается: «Государства водотока могут заключить одно или несколько соглашений, именуемых ниже соглашениями о водотоке, о применении и приспособлении положений настоящей Конвенции к характеристикам и видам использования данного водотока или его части». 
позволило бы завершить работу над проектом этой Конвенции в $\mathrm{OOH}$, пока безуспешны. В этой ситуации заключен ряд региональных соглашений с различными определениями терроризма. В рамках Лиги арабских государств в 1998 году заключена Конвенция о борьбе с терроризмом $^{56}$. В 1999 году заключены Договор о сотрудничестве между государствами - членами СНГ в борьбе с терроризмом, Конвенция Организации исламская конференция о борьбе с международным терроризмом и Конвенция Организации африканского единства о предотвращении и борьбе с терроризмом ${ }^{57}$. Все они содержали разные определения этого преступления. В заключенной в 2002 году Межамериканской конвенции против терроризма ${ }^{58}$ такого определения нет. Лишь в Европе идея заключения аналогичного регионального договора пока не получила развития ${ }^{59}$. Такое региональное разнообразие в подходах к определению терроризма мешает достижению согласия на универсальном уровне. Это реальность, которая, безусловно, сушественно влияет на нормотворчество на универсальном уровне во многих областях. Как отмечает Дж. Кроуфорд, «разнообразие государств и тенденция к регионализации... создают серьезные проблемы для международного права и даже могут поставить под вопрос его претензии на универсальность ${ }^{60}$.

В то же время не менее очевидно, что более оперативное формирование международно-правовых норм в регионах играет и важную положительную роль для создания универсальных норм. Выше отмечалось, что региональные нормы становятся моделью или базой для универсальных норм. Так происходит во многих случаях. Появление региональных норм по крайней мере стимулирует универсальный переговорный процесс. Для того чтобы регионализм играл такую роль, необходимо, чтобы сама проблема непременно требовала не только ${ }^{56}$ International instruments related to the Prevention and Suppression of International Terrorism. New York, 2001. P. 152.

${ }^{57}$ Ibid. P. 174, 187, 220.

s8 Ibid. P. 210.

${ }^{59}$ Европейская конвенция о борьбе с терроризмом 1977 года посвящена главным образом вопросам выдачи (ЕTS № 90). Однако ряд государств - членов Совета Европы, в котором обсуждается вопрос о новом «всеобъемлющем» региональном договоре, считают, что его заключение было бы контрпродуктивным с точки зрения усилий в рамках $\mathrm{OOH}$.

${ }^{60}$ Crawford J. Universalism and regionalism from the perspective of the work of the International law commission. In: International Law on the Eve of the Twenty-first Century. Views from the International Law Commission, UN, New York, 1997. P. 102. 
регионального, но и универсального ответа. Терроризм - пример именно такой проблемы ${ }^{6 !}$. Не случайно ею занимаются не только в $\mathrm{OOH}$, но и практически во всех регионах мира. Важно, что региональные конвенции опираются, во-первых, на основные принципы международного права, а во-вторых, на действующие универсальные т.н. секторальные антитеррористические конвенции. Соответственно, несмотря на региональное разнообразие и отсутствие в данный момент прогресса на переговорах в ООН, заключение универсальной всеобъемлющей конвенции - вопрос времени. Можно предположить, что в конце концов региональная активность окажется позитивным фактором для формирования универсального режима. Тот же Дж. Кроуфорд, анализируя отношения между универсализмом и регионализмом, пишет: «Идеал универсальности может быть достигнут только на основе определенного допущения расхождений в частностях ${ }^{62}$.

Изложенное позволяет сделать следующие выводы.

Угроза фрагментации международного права (если под фрагментацией понимается распад международно-правовой системы на отдельные не связанные между собой части) вряд ли реальна. Для фрагментации нет объективных предпосылок. Наоборот. Несмотря на индивидуальное, групповое, региональное разнообразие государств, глобализация диктует необходимость выработки универсальных норм для регулирования все новых и новых вопросов, а прекращение противостояния двух мировых систем создает для формирования таких норм благоприятную среду.

Международное право является всеобъемлющей системой в том смысле, что по крайней мере на уровне ее самых общих, основных принципов она охватывает все отношения, являющиеся предметом международно-правового регулирования. Формирование новых норм, заполняющих конкретные пробелы, происходит на базе принципов международного права, в рамках его системы ${ }^{63}$. Эта система постоян-

${ }^{61}$ Свидетельство этому - резолюции Генеральной Ассамблеи и Совета Безопасности ООН, посвященные терроризму (например, резолюции Генерапьной Ассамблеи 49/60 от 9 декабря 1994 года; 51/210 от 17 декабря 1996 года; 52/165 от 15 декабря 1997 года; 53/108 от 8 декабря 1998 года; 54/110 от 9 декабря 1999 года; 55/158 от 12 декабря 2000 года; 56/1 от 12 сентября 2001 года; 57/27 от 19 ноября 2002 года; 58/81 от 9 декабря 2004 года; резолюции Совета Безопасности 1368 (2001); 1373 (2001); 1377 (2001) и др.

${ }^{62}$ Crawford J. Op. cit. P. 119.

${ }^{63}$ Дж. Поувелин пишет, чпо государства могут заключать соглашения, отступаюшие от одной или, в теории, от всех норм общего международного права (за исключением норм јus cogens), 
но развивается вместе с отношениями, которые она регулирует. Наряду с заполнением конкретных пробелов происходит изменение действующих норм. Нередко такие изменения начинаются с возникновения отличающихся от действующей нормы специальных универсальных или региональных норм. Это возможно, когда действующая норма имеет диспозитивный характер.

Система международного права позволяет решать конфликты, возникающие в связи с формированием новых международно-правовых норм, между старыми и новыми нормами. Один из способов решения таких конфликтов - применение общих для всех правовых систем правил юридической техники, таких, в частности, как превалирование нормы специальной над нормой общей, последуюшей - над предыдущей.

Решающее слово в этих процессах принадлежит государствам. Сама по себе деятельность международных органов по урегулированию споров или иных договорных органов, толкующих и применяющих нормы международного права, при всей ее значимости не приводит к созданию новых международно-правовых норм или изменению действующих. Важна реакция государств на эту деятельность, их дальнейшая практика. Различные решения международных судов в схожих ситуациях могут являться знаком того, что конкретная норма международного права, регулирующая такие ситуации, еше только формируется. Каково будет ее содержание, зависит прежде всего от позиции государств на сей счет.

В то же время гипотетический характер угрозы фрагментации не означает, что государствам не следует уделять этому вопросу внимание. Для государств важно отслеживать деятельность международных органов, применяющих и толкующих международное право, в частности, с точки зрения их деятельности в контексте системы международного права, реагировать в соответствующих случаях на нее. Государствам следует побуждать эти органы к ознакомлению с деятельностью друг друга, внимательному отношению к ней. Нельзя исключать создания в соответствующих случаях механизмов, обеспечивающих гармонизацию деятельности таких органов. (Например, Совет Безопасности ООН счел необходимым, чтобы у Трибуналов по Руанде и бывшей Югославии была единая апелляционная палата.)

но они не могут заключать соглашения вне рамок системы международного права. Государства автоматически и в обязательном порядке заключают соглашения в рамках системы международного права. Pauwelyn J. Op. cit. P. 539. По-видимому, это утверждение верно и для формирования обычных международно-правовых норм. 
Полезным может быть включение в международные договоры положений, ясно указывающих на их соотношение с другими международно-правовыми нормами в регулируемой ими области.

Важно, что изучение данной темы поручено Комиссии международного права, которая может предложить вниманию государств рекомендации по обеспечению дальнейшего гармоничного развития международного права. Однако в конечном счете именно государства несут основную ответственность за сохранение целостности системы международного права и использование тех благоприятньх условий, которые сложились на рубеже XX-XXI веков, для ее дальнейшего развития. 